\title{
PENGELOLAAN PEMBELAJARAN BAHASA INDONESIA DENGAN MENGGUNAKAN METODE KONTEKSTUAL DI SLTP NEGERI 25 SURABAYA
}

\author{
Oleb: \\ Yulia Krisnawati
}

\begin{abstract}
Abstrak
Berdasarkan studi awal yang dilakukan oleh peneliti di kelas 1A SLTP Negeri 25 Surabaya, salah satu penyebab siswa kurang berminat belajar bahasa Indonesia karena guru kurang kreatif dan inovatif dalam menerapkan metode pembelajaran. Metode kontekstual dalam pembelajaran bahasa Indonesia merupakan salah satu alternatif untuk mengatasi masalah dalam pembelajaran. Dengan metode kontekstual ini, siswa dikondisikan untuk berpikir secara kritis, kreatif, logis, dan analitis.

Penelitian ini merupakan penelitian tindakan kelas, rancangan penelitian disusun secara kolaboratif dalam 3 siklus, yang masing-masing terdiri dari (1) perencanaan, (2) tindakan, (3) observasi, dan (4) refleksi. Data penelitian berupa data proses dan hasil tindakan yang diperoleh dari hasil pengamatan, hasil wawancara, kumpulan catatan lapangan, dan dokumentasi berupa rekaman audio visual. Analisis data dilaksanakan melalui reduksi data, penyajian data, dan penarikan kesimpulan. Untuk menguji keabsahan data dilakukan triangulasi data.

Hasil penelitian menunjukkan bahwa penerapan metode kontekstual dalam pembelajaran bahasa Indonesia mampu mengubah paradigma guru tentang metode pembelajaran, guru tidak lagi berorientasi student centered teacbing, tetapi student centered learning. Guru kreatif dengan melakukan inovasi pembelajaran sehingga mampu membangkitkan semangat belajar siswa. Siswa tidak lagi bosan dan tegang mengikuti pembelajaran bahasa Indonesia sehingga pembelajaran bahasa Indonesia menjadi menyenangkan.
\end{abstract}

Kata kunci: pengelolaan pembelajaran babasa Indonesia, metode kontelestuah motivasi, berpikir kritis, student centered learring 
Pengelolaan Pembelajaran Babasa Indonesia dengan Menggunatean Metode Kontekstual di SLTP Negeri 25 Sumabaga

\section{Pendahuluan}

Kemajuan kehidupan suatu bangsa sangat ditentukan oleh pendidikan. Pendidikan yang tertata dengan baik dapat menciptakan generasi yang berkualitas, cerdas, adaptif, dan bermoral. Untuk mencapai tujuan tersebut di atas, Departemen Pendidikan Nasional telah melakukan berbagai upaya untuk meningkatkan mutu pendidikan, antara lain dengan mengadakan berbagai pelatihan dan peningkatan kualitas guru, penyempurnaan kurikulum, pengadaan buku, alat pelajaran, dan masih banyak lagi. Meskipun demikian, hasilnya masih jauh dari memuaskan.

Berdasarkan data Human Development Report 2003, peringkat kualitas sumber daya manusia Indonesia berada pada urutan 112. Indonesia berada jauh di bawah Filipina (85), Thailand (74), Malaysia (58), Brunai Darusalam (31), dan Singapura (28). Salah satu penyebabnya adalah unsur guru, terutama dalam penggunaan strategi, pemilihan metode pembelajaran, bahan ajar, dan teknik penilaian. Hal ini benar-benar berpengaruh terhadap hasil pembelajaran.

Pada saat ini, di kelas pembelajaran bahasa Indonesia masih banyak dijumpai guru yang menggunakan metode pembelajaran konvensional, guru kurang memberda-yakan pemakaian media pembelajaran, dan guru masih kurang kreatif dalam mengelola pembelajaran bahasa Indonesia di kelas. Seorang pengajar bahasa Indonesia dituntut serius dalam meningkatkan kinerjanya. Pengajar bahasa Indonesia perlu menguasai dan mampu menerapkan berbagai pendekatan dan metode dalam proses belajar mengajar di dalam kelas. Dalam pembelajaran bahasa Indonesia peran guru sangat besar, guru benarbenar ditantang untuk menghadirkan metode yang memadai dan cocok untuk menunjang tercapainya tujuan pembelajaran bahasa Indonesia tersebut.

Suatu hal yang merupakan pencerahan, karena pada saat ini berkembang pemikiran di kalangan para ahli pendidikan bahwa anak akan belajar lebih baik jika lingkungan diciptakan alamiah. Belajar akan lebih bermakna jika anak 'mengalami' apa yang dipelajarinya, tidak hanya 'mengetahui' saja. Menurut Nurhadi (2002) pembelajaran kontekstual (Contextual Teacbing and Learning) merupakan konsep belajar yang membantu guru mengaitkan antara materi yang diajarkannya dengan situasi dunia nyata siswa dan mendorong siswa 
membuat hubungan antara pengetahuan yang dimilikinya dengan penerapannya dalam kehidupan mereka sebagai anggota keluarga dan masyarakat. Dengan konsep itu, hasil pembelajaran diharapkan lebih bermakna bagi siswa. Proses pembelajaran berlangsung alamiah dalam bentuk kegiatan siswa bekerja dan mengalami, bukan transfer pengetahuan dari guru ke siswa. Strategi pembelajaran lebih dipentingkan daripada hasil.

Pembelajaran bahasa Indonesia seharusnya dikembalikan pada kedudukan yang sebenarnya, yaitu melatih siswa membaca sebanyak-banyaknya, menulis sebanyak-banyaknya, berdiskusi sebanyak-banyaknya. Misalnya, membaca berita, artikel, novel, cerpen, iklan, dan sebagainya sebanyakbanyaknya, atau berlatih menulis berita, berlatih menulis surat, berlatih menulis iklan, berlatih menulis cerpen, dan sebagainya secara terus-menerus. Pengajaran bahasa Indonesia pada hakikatnya adalah kegiatan melatih siswa meningkatkan kemampuan berbahasa Indonesia, baik lisan maupun tulis. Pengajaran bahasa Indonesia selayaknya penuh dengan kegiatan berlatih berbahasa, bukan penyampaian pengetahuan mengenai bahasa Indonesia. Faktanya, kemampuan berbahasa apa pun, umumnya diperoleh melalui kegiatan berlatih terus-menerus dalam bahasa itu.

\section{Pengertian Pembelajaran Kontekstual}

Konsep kontekstual ditempatkan dari pemikiran abstrak ke kongkrit di dalam pembelajaran untuk membantu guru-guru menghubungkan isi mata pelajaran dengan situasi sebenarnya dan memotivasi siswa untuk membuat hubungan-hubungan antara pengetahuan serta penerapannya di dalam kehidupan mereka.

James Le Marquad (2001) menyatakan bahwa aplikasi pembelajaran kontekstual di ruang kelas di Amerika pertama kali dilakukan oleh John Dewey. 'People bave used such terms as discovery learning, experiential learning, real world education, active learning and learner centered instruction to mean similar ideas. "Berdasarkan pengertian tersebut di atas, pembelajaran kontekstual diartikan pembelajaran penemuan, pembelajaran berdasarkan pengalaman, pendidikan dunia nyata, pembelajaran aktif, dan pembelajaran yang berdasarkan instruksi untuk 
mempertunjukkan ide-ide yang sama. Lebih lanjut, dikatakan olehnya pembelajaran kontekstual benar-benar bermaksud menciptakan dan memelihara suatu lingkungan pembelajaran yang menyenangkan, nyata, serta dapat diperoleh bagi seluruh muridnya.

Nurhadi (2002) mengemukakan hakikat pembelajaran kontekstual (contextual teacbing and learning) adalah konsep belajar yang membantu guru mengaitkan antara materi yang diajarkannya dengan situasi dunia nyata siswa dan mendorong siswa membuat hubungan antara pengetahuan yang dimilikinya dengan penerapannya dalam kehidupan sehari-hari, dengan melibatkan tujuh komponen utama pembelajaran efektif yakni konstruktifistik (Constructivism), bertanya (Questioning), menemukan (Inquiry), masyarakat belajar (Learning community), pemodelan (Modeling), dan penilaian yang tiil (Authentic assessment).).

O' Flanagan (2001) menyebutkan teori pembelajaran kontekstual terjadi hanya ketika murid (pembelajar) mengolah informasi atau pengetahuan baru dengan cara yang membuat hal itu masuk akal bagi siswa dalam kerangka referensi siswa sendiri (di dalam pusat ingatan, pengalaman, dan respons milik ia sendiri). Sejalan dengan hal itu, Gold Berger (2001) dalam Contextual teaching and learning menyatakan pembelajaran kontekstual adalah pembelajaran yang terjadi dalam kaitan yang erat dengan pengalaman yang aktual.

\section{Elemen Pembelajaran Kontekstual}

Lima elemen belajar yang konstruktivistik yang harus diperhatikan dalam pembelajaran kontekstual menurut Zaborik (Nurhadi, 2002: 7) adalah: (1) pengaktifan pengetahuan yang sudah ada (activating knowledge); (2) pemerolehan pengetahuan baru (acquiring knowledge) dengan cara mempelajari secara keseluruhan dulu, kemudian memperhatikan detailnya; (3) pemahaman pengetahuan (understanding knowledge), yaitu dengan cara menyusun konsep sementara atau hipotesis, melakukan sharing kepada orang lain agar mendapat tanggapan atau validasi dan atas dasar tanggapan itu konsep tersebut direvisi atau dikembangkan; (4) mempraktikkan pengetahuan dan pengalaman tersebut (apphying knowledge); (5) melakukan refleksi (reflecting knowledge) terhadap strategi pengembangan pengetahuan tersebut. 


\section{Karakteristik Pendekatan Kontekstual}

Menurut Endah Priyatni (2003: 22) pembelajaran yang dilaksanakan dengan menggunakan metode kontekstual memiliki karakteristik sebagai berikut: (1) pembelajaran yang dilaksanakan dalam konteks yang otentik, artinya pembelajaran diarahkan agar siswa memiliki keterampilan dalam memecahkan masalah nyata yang dihadapi; 2) pembelajaran memberikan kesempatan kepada siswa untuk mengerjakan tugas-tugas yang bermakna; (3) pembelajaran dilaksanakan dengan memberikan pengalaman bermakna kepada siswa; (4) pembelajaran dilaksanakan melalui kerja kelompok, berdiskusi, saling mengoreksi; (5) kebersamaan, kerjasama, dan saling memahami satu dengan yang lain secara mendalam merupakan aspek pembelajaran yang menyenangkan; (6) pembelajaran dilaksanakan secara aktif, kreatif, produktif, dan mementingkan kerjasama, (7) pembelajaran dilaksanakan dengan cara menyenangkan.

\section{Kata Kunci dalam Pembelajaran Kontekstual}

Untuk mempermudah dalam memahami pembelajaran kontekstual Nurhadi (2002: 6) menandai dengan: (1) real world learning (2) mengutamakan pengalaman nyata; (3) berpikir tingkat tinggi; (4) berpusat pada siswa; (5) siswa aktif, kritis, dan kreatif; (6) pengetahuan bermakna dalam kehidupan; (7) dekat dengan kehidupan nyata; (8) perubahan perilaku; (9) siswa praktik bukan menghafal; (10) learning bukan teaching, (11) pendidikan (education) bukan pengajaran (instruction); (12) pembentukan manusia; (13) memecahkan masalah; (14) siswa 'acting' dan guru mengarahkan; (16) hasil belajar diukur dengan berbagai cara tidak hanya dengan tes.

\section{Pengajaran Bahasa Indonesia dengan Menggunakan Metode Kontekstual}

Konsep Pendekatan Kontekstual dan Penerapannya di Kelas

Tujuan utama pembelajaran CTL adalah agar siswa mengerti apa makna belajar, apa manfaatnya, dalam status apa mereka, dan bagaimana mencapainya. Mereka sadar bahwa yang mereka pelajari berguna bagi hidupnya kelak. Dengan 
demikian, mereka memposisikan sebagai diri sendiri yang memerlukan suatu bekal untuk hidupnya nanti. Mereka mempelajari apa yang bermanfaat bagi dirinya dan berupaya menggapainya. Dalam upaya itu, mereka memerlukan guru sebagai pengarah dan pembimbing. Bahan ajar disusun untuk menunjang proses tersebut.

Dalam kelas kontekstual, tugas guru adalah membantu siswa mencapai tujuannya. Maksudnya, guru lebih banyak berurusan dengan strategi daripada memberi informasi. Tugas guru mengelola kelas sebagai sebuah tim yang bekerja bersama untuk menemukan sesuatu yang baru bagi anggota kelas (siswa). Sesuatu yang baru (baca: pengetahuan dan keterampilan) datang dari 'menemukan sendiri', bukan dari 'apa kata guru'. Begitulah peran guru di kelas yang berbasis CTL.

Dalam pembelajaran bahasa Indonesia, ada empat keterampilan dasar berbahasa yang dilatihkan, yaitu membaca, mendengarkan, berbicara, dan menulis. Keempat keterampilan itu disusun bahan ajarnya berdasarkan GBPP bahasa Indonesia SLTP. Dalam bahan ajar itu, siswa dilatih untuk memecahkan masalah, menemukan sesuatu yang berguna bagi dirinya, dan bergelut dengan ide-ide. Siswa harus mengonstruksikan pengetahuan di benak mereka sendiri. Menurut pendekatan CTL, siswa harus menemukan dan mentransformasikan pengetahuan serta keterampilan yang diperoleh-nya.

Berdasarkan latar belakang masalah di atas, maka disusun pertanyaan penelitian sebagai berikut: 1) Sejauh mana pengelolaan pembelajaran bahasa Indonesia dengan menggunakan metode kontekstual dapat meningkatkan proses pembelajaran?; 2) Sejauh mana penggunaan metode kontekstual dalam pembelajaran bahasa Indonesia dapat menciptakan suasana kelas yang bergairah, aktif, dan menyenangkan? ; 3) Sejauh mana penggunaan metode kontekstual dalam pembelajaran bahasa Indonesia dapat membawa siswa membangun sendiri pengetahuan yang dimiliki melalui keterlibatan aktif dalam pembelajaran?

\section{Metode Penelitian}

Penelitian ini dilaksanakan di SLTP Negeri 25 Surabaya dengan menggunakan rancangan penelitian tindakan kelas (action researcb). 
Proses pelaksanaan penelitian tindakan ini bersifat kolaboratif, yaitu kerjasama antara peneliti dengan guru mata pelajaran. Data berupa seperangkat pembelajaran dan rekaman proses pembelajaran bahasa Indonesia yang telah dikembangkan dengan pendekatan CTL. Sasaran penelitian ini adalah siswa SLTP Negeri 25 Surabaya. Peneliti sebagai instrumen kunci, yaitu sebagai pengembang perangkat materi, perekam data, penganalisis, dan penyimpul hasil penelitian berkolaborasi dengan dua orang guru bahasa Indonesia yang telah mengikuti penataran serta pelatihan tentang metode pengajaran kontekstual.

Langkah-langkah penelitian tersebut dapat digambarkan sebagai berikut:

\section{Model Langkah-Langkah Penelitian Tindakan Kelas Menurut Mckernan}
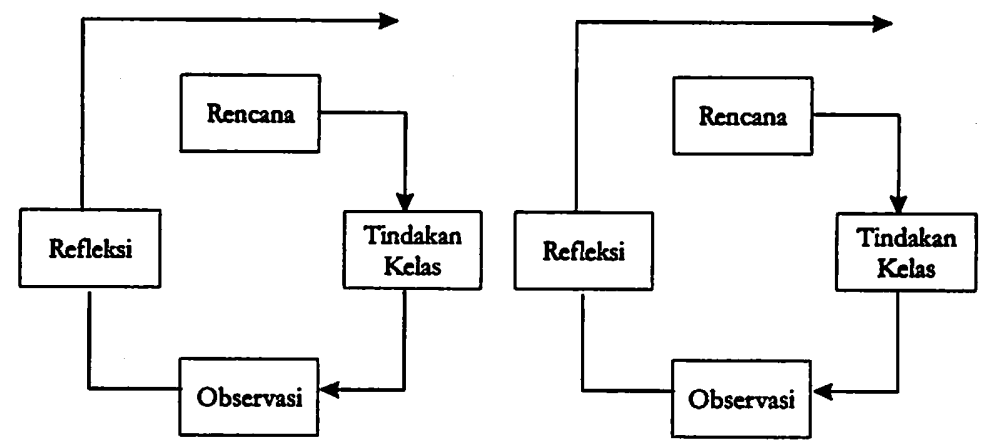

Dalam setiap pelaksanaan penelitian, validitas merupakan salah satu syarat yang penting, penelitian tindakan ini menggunakan validitas demokratik, dialogis, katalitik, proses, dan validitas hasil, sedangkan reliabilitas penelitian ini dapat dicapai dengan triangulasi, yaitu dengan berbagai metode pengumpulan data seperti angket, observasi, dan wawancara, perekaman data melalui audio visual. Data-data hasil pengamatan dapat divalidasi dengan hasil angket yang terkait ataupun data yang diperoleh dari wawancara.

Penelitian tindakan kelas ini menggunakan teknik analisis kualitatif, dengan penekanan pada penelitian tindakan kelas sehingga data yang diperoleh bukan dalam bentuk angka. Data yang diperoleh, diolah dengan menggunakan langkahlangkah kegiatan (a) reduksi data, (b) penyajian data, (c) penyimpulan data. Kegiatan pada masing-masing langkah analisis diuraikan sebagai berikut. 
Kegiatan analisis data diawali dengan kegiatan reduksi data. Kegiatan yang dilakukan pada tahap ini adalah mengidentifikasi data tentang perencanaan, pelaksanaan, dan hasil pembelajaran bahasa Indonesia dengan menggunakan metode kontekstual. Kegiatan tersebut dilanjutkan dengan proses deskripsi terhadap data yang telah diidentifikasikan. Setelah dilakukan identifikasi, klasifikasi, kegiatan analisis data dilanjutkan proses penyajian data. Data tersebut mula-mula disajikan secara terpisah, tetapi setelah tindakan terakhir direduksi, keseluruhan data tindakan dirangkum dan disajikan secara terpadu.

Kegiatan terakhir analisis data adalah kegiatan penyimpulan hasil penelitian dan triangulasi. Kegiatan ini merupakan penyimpulan akhir temuan penelitian yang diikuti dengan kegiatan triangulasi data atau pengujian temuan penelitian. Kegiatan triangulasi dilakukan dengan cara menanyakan hal yang sama kepada responden lain. Di samping itu, dilakukan pula: (a) meninjau kembali catatan lapangan, dan (b) bertukar pikiran dengan ahli, teman sejawat, serta guru (validasi sejawat).

\section{Hasil Penelitian dan Pembahasan}

Hasil penelitian menunjukkan terdapat beberapa perubahan pada siswa, setelah paradigma guru tentang metode pembelajaran berubah. Kegiatan pembelajaran bahasa Indonesia tidak lagi mengunakan metode behavioristik, tetapi guru telah mengunakan metode pembelajaran kontekstual. Selama berlangsungnya pembelajaran, guru tidak hanya berceramah, tetapi dengan mengunakan berbagai cara dan memanfaatkan media belajar yang telah disesuaikan dengan materi pembelajaran berupa lingkungan sekolah.

Penerapan metode kontekstual di dalamnya terdapat komponenkomponen pembelajaran yang meliputi:

a. Konstruktivisme: Yaitu siswa belajar berdasarkan pengalaman nyata, dengan mengamati objek secara langsung, siswa didekatkan pada hal-hal yang bersifat faktual bukan hanya sekedar teoretis saja. Dengan cara belajar seperti ini, siswa belajar bahasa Indonesia menjadi lebih bermakna, siswa merasa senang, sehingga suasana kelas menjadi kondusif..Ada seorang siswa yang menyampaikan rasa kegembiraan-nya pada guru. "Saya senang Bu, baru 
sekarang ini saya belajar babasa dengan cara begini, dulu saya di SD guru saya tidak pernah mengajarkan seperti ini." Jadi, penggunaan metode kontekstual bagi siswa merupakan pengalaman baru yang menyenangkan.

b. Dengan hadirnya inkuiri dalam pembelajaran bahasa Indonesia, siswa nampak bergairah, tidak ada siswa yang ogah-ogahan belajar, gaduh dalam kelas, atau perhatian mereka tertuju ke luar kelas atau bahkan mengantuk, seluruh siswa terlibat dalam aktivitas pembelajaran.

c. Dalam komponen questioning inilah yang merupakan bagian terseru dalam pembelajaran bahasa Indonesia, siswa yang mempunyai potensi dan pemberani semakin kelihatan menonjol kemampuannya, sehingga siswa yang biasanya pendiam akhirnya terpengaruh untuk ikut serta bertanya, meskipun pertanyaan tersebut dilakukan hanya pada sesama teman dalam kelompoknya saja, bukan pada kelompok lain. Pada tahap penyimpulan pun siswa tidak sábar meminta pada guru untuk mengumumkan kelompok manakah yang terbaik, padahal perencanaan guru sebelumnya tidak sampai pada tahapan mengumumkan kelompok yang terbaik. Situasi pembelajaran benar-benar hidup.

d. Penciptaan kelompok belajar (learning community), di sini benar-benar menjadi ajang sharing ideas antar siswa. Tiap-tiap kelompok berdiskusi dengan anggota kelompoknya dalam menyelesaikan tugas yang diberikan oleh guru, tidak jarang dalam kelompok tersebut terjadi perdebatan-perdebatan kecil. Terlihat pada saat salah satu anggota kelompoknya presentasi ke depan kelas, mendapat pertanyaan dari kelompok lain, anggota kelompoknya tidak segansegan membantu, meskipun kadang-kadang argumenasi yang disampaikan tidak tepat pada sasaran. Dari sini tampak adanya kebersamaan, mereka tidak membeda-bedakan siswa pandai dan yang "kurang", sehingga dengan adanya masyarakat belajar ini terjadi interaksi positif antara kedua jenis siswa yang mempunyai potensi yang berbeda.

Penggunaan metode kontekstual pada pembelajaran bahasa Indonesia ini, ternyata mampu membangun situasi belajar yang konduksif. Siswa belajar dalam kondisi tidak tertekan, siswa tidak merasa tegang, belajar terasa menyenangkan, sehingga selama proses belajar mengajar ber-langsung tidak 
ada siswa yang merasa bosan. Pada saat peneliti menyebarkan angket pada siswa, semua siswa menyatakan menyukai pembelajaran dengan menggunakan metode kontekstual, dengan berbagai alasan, ada yang menyatakan suka karena merupakan pengalaman pertama belajar dengan menggunakan metode tersebut, dapat bertanya sepuas-puasnya, merasa tidak takut lagi mengemukakan pendapat, suasana belajar tidak menegangkan, dapat memahami materi dengan mudah, dll.

Untuk meningkatkan semangat siswa, sebenarnya guru dapat memberi reward dalam bentuk pujian, tepuk tangan atau juga memajang hasil karya mereka di kelas sebagai bentuk penghargaan. Saat diterapkan metode behavioristik dan setelah diterapkannya metode kontekstual, secara umum dirasakan bahwa perubahan tidak terjadi secara drastis, namun setahap demi setahap dalam setiap siklus. Siswa telah terkondisikan belajar bahasa Indonesia itu menyenangkan, hal itu merupakan aspek yang mendukung terciptanya proses belajar bahasa Indonesia yang efektif. Belajar dalam suasana yang menyenangkan, mendorong siswa menjadi aktif dalam membangun atau mengonstruk pengetahuan melalui inquiry, atau bertanya, siswa dapat sharing, belajar, dan berinteraksi secara positif dengan siswa lainnya. Metode kontekstual ini sudah saatnya disosialisasikan, sehingga guru dapat melaksanakan metode tersebut di kelas agar bermanfaat bagi peningkatan mutu pembelajaran bahasa Indonesia.

Bertolak dari rasa senang di atas, hal itu mengingatkan pada peneliti bahwa salah satu faktor penting keberhasilan dalam sebuah pengajaran adalah timbulnya rasa senang dan puas dengan apa yang dilakukan, serta rasa senang tersebut apabila dipupuk akan sangat membantu pencapaian hasil belajar yang diinginkan, sehingga dengan timbulnya rasa senang selama pembelajaran bahasa Indonesia diharapkan akan ada korelasinya dengan penguasaan keterampilan berbahasa siswa.

\section{Simpulan}

Berdasarkan pelaksanaan tindakan dan refleksi yang dilakukan dalam penelitian ini, maka dapatlah ditarik simpulan sebagai berikut.

1. Penggunaan metode pembelajaran dari metode behaviorisme ke metode 
yang konstruktivisme telah mampu mengubah paradigma guru tentang metode pembelajaran. Guru tidak lagi menjadi satu-satunya nara sumber dalam pembelajaran dan kegiatan telah beralih menjadi siswa sebagai pusat kegiatan pembelajaran serta peran guru hanya sebagai motivator dan fasilitator saja.

2. Dengan dipahaminya metode pembelajaran yang konstruktivistik oleh guru, maka guru kreatif dengan melakukan inovasi pada materi pembelajaran, dengan adanya penciptaan variasi bahan pembelajaran yang dilakukan oleh guru semangat siswa mampu dibangkitkan.

3. Penggunaan media yang bervariasi, dengan memanfaatkan benda-benda sederhana yang mudah didapat sampai dengan elektronik ternyata sangat membantu siswa dalam memahami materi yang dipelajari, siswa lebih mudah memahami materi apabila menggunakan media pembelajaran.

4. Penerapan kegiatan mengonstruk atau membangun sendiri pengetahuan pada siswa, membuat siswa terlatih untuk bernalar dan berfikir secara kritis karena mereka belajar melalui pengalaman nyata sehingga hasil belajar akan lebih bermakna.

5. kegiatan menemukan sendiri atau inkuiri dapat membuat siswa semakin bergairah dalam pembelajaran, selama berlangsungnya pembelajaran siswa penuh dengan aktivitas dan pada diri siswa muncul rasa bangga serta puas karena mampu menemukan sendiri apa yang dipelajarinya.

6. Adanya kebebasan bertanya (questioning) siswa dapat mengubah sikap dan kebiasaan yang semula diam, pasif, dan takut mengemukakan pendapat menjadi antusias dalam belajar sehingga suasana belajar menjadi, 'hidup'.

7. Penerapan masyarakat belajar (learning community) telah melatih siswa untuk bekerjasama, sharing ideas, saling berbagi pengalaman, pengetahuan, saling berkomunikasi sehingga terjadi interaksi yang positif antarsiswa dan pada akhirnya siswa terlibat aktif belajar bersama-sama.

8. Pemberian reward kepada siswa dalam bentuk pujian, tepuk tangan, dan memajang hasil karya siswa di kelas telah mampu meningkatkan semangat belajar dan tanggung jawab siswa karena hasil karyanya merasa dihargai oleh guru. 


\section{Saran-saran}

Peneliti mengemukakan saran-saran sebagai berikut.

1. Saran kepada Guru bahasa Indonesia

Hasil penelitian ini diharapkan dapat dimanfaatkan oleh guru bahasa Indonesia sebagai salah satu alternatif pembelajaran bahasa Indonesia di SLTP, dengan memperhatikan beberapa hal yakni:

a. Kreativitas guru diperlukan dengan melakukan inovasi pada materi pembelajaran, dengan penciptaan variasi bahan pembelajaran sehingga siswa tidak lagi tegang dan bosan mengikuti pelajaran serta menggunakan media yang bervariasi, dengan memanfaatkan benda-benda sederhana yang mudah didapat untuk membantu siswa dalam memahami materi yang dipelajari.

b. Melalui kegiatan menemukan sendiri selama berlangsungnya pembelajaran, diharapkan agar muncul rasa bangga dan puas karena mampu menemukan sendiri apa yang dipelajarinya.

c. Melatih siswa untuk bekerjasama, sharing ideas, saling berbagi pengalaman, pengetahuan, komunikasi timbal balik sehingga terjadi interaksi yang positif antarsiswa dan pada akhirnya siswa terlibat aktif belajar bersamasama.

2. Saran kepada Kepala Sekolah

Dari hasil penelitian ini, kami menyarankan kepada kepala sekolah untuk mendapatkan hasil yang maksimal atas mutu pengajaran yang lebih baik sebagai berikut.

a. Membina para guru untuk berupaya menggunakan metode yang konstruktivistik dalam pembelajaran di kelas.

b. Membuat standar pengukuran keberhasilan mengajar dan kompetensi yang diperlukan sebagai dasar penilaian kinerja guru.

c. Meningkatkan sarana pembelajaran dengan melengkapi buku-buku perpustakaan untuk menambah wawasan dan pengetahuan guru serta siswa. 


\section{Saran Kepada Peneliti}

Disarankan kepada peneliti yang lain agar dapat melakukan penelitian yang serupa untuk mengkaji, menelaah, dan memperdalam pengelolaan pembelajaran dalam penelitian tindakan kelas. Selain itu, diharapkan ada penelitian lanjutan sehingga dapat melengkapi kekurangan yang terdapat dalam penelitian ini.

\section{Daftar Pustaka}

Baily, T. R. \& Berryman. (2001). Contextually Based Learning. Diambil pada tanggal 11 Juni 2001, dari http//www.contextual.org.

Baraja, M. Farid. (1990). Kapita Selekta Pengajaran Babasa. Malang: Penerbit IKIP Malang.

Berger, Gold. (2001). Contextual Teaching Learning. Diambil pada tanggal 11 Juni 2001), dari http//www.stw.ed.gov.

Depdibud. (1993). Garis-Garis Besar Program Pengajaran Sekolab Lanjutan Tingkat Pertama. Jakarta: Departemen Pendidikan dan kebudayaan.

Kasbolah, Kasihani. E. S. (2002). Penelitian Tindakan Kelas Sebagai Refleksi Pengajaran Guru SLTP. Kumpulan materi TOT CTL mata pelajaran bahasa Inggris. Malang: Fakultas Sastra: Universitas Negeri Malang.

Kember, David. (2000). Action Learning and Action Research. Northamptonshire: Wellingborough.

Lie, Anita. (2002). Cooperative Learning Mempraktikkan: Cooperative Learning Ruang-ruang Kelas. Jakarta: Gramedia.

Madya, Suwarsih. (1994). Panduan Penelitian Tindakan. Yogyakarta: Lembaga Penelitian IKIP Yogyakarta.

Marquand, James Le. (2001). Contextual Learning and Approach to Teaching Student with Intellectual Sisability. Diambil pada tanggal 11 Juni 2001 dari http://www. arohanui. school. $\mathrm{nz} /$ contextual learning. htm.

Moleong, Lexy. (1990). Metodologi Penelitian Kualitatif. Bandung: Remaja Rosda Karya. 
Nurhadi. (2002). Pendekatan Kontekstual. Departemen Pendidikan Nasional. Direktorat Jenderal Pendidikan Dasar Menengah. Direktorat Pendidikan Lanjutan Pertama. - (2003) Kontekstual dan Penerapanmya dalam KBK. Malang: Universitas Negeri Malang.

O' Flanagan. (2001). What is Contextual Teacbing and Learning. Diambil pada tanggal 21 Juni 2001, dari http://www.cord.org/lev2efm/56

Soeparno. (2001). Pembelajaran Babasa Indonesia dengan Pendekeatan Kontelestual. Makalah disajikan dalam seminar sehari menyongsong pemberlakuan kurikulum baru bidang studi Bahasa Indonesia, di Unversitas Negeri Malang.

Soetomo. (19930. Dasar-dasar Interaksi Belajar Mengajar. Surabaya: Usaha Nasional.

Suyono. (1990). Pragmatik Dasar-dasar Pengajaran. Malang: YA3. 